\title{
Influence of NADPH oxidase on inflammatory response in primary intestinal epithelial cells in patients with ulcerative colitis
}

\author{
Rima Ramonaite ${ }^{1 \dagger}$, Jurgita Skieceviciene ${ }^{1 \dagger}$, Gediminas Kiudelis$^{2}$, Laimas Jonaitis ${ }^{2}$, Algimantas Tamelis ${ }^{3}$,
} Paulius Cizas ${ }^{4}$, Vilmante Borutaite ${ }^{4 \dagger}$ and Limas Kupcinskas ${ }^{1,2^{*}}$

\begin{abstract}
Background: The aim of this study is to evaluate the role of NADPH oxidase in primary intestinal epithelial cells during the active phase of UC.

Methods: The primary human colonic epithelial cells were isolated from 19 patients with mild to moderate inflammatory activity of UC and 14 controls using chelation method. The cells were cultivated under the effect of mediators. Viability of cells was assessed by fluorescent microscopy. Production of reactive oxygen species (ROS) by the cells was measured fluorimetrically using Amplex Red. Production of TNF-a cytokine by the colonic epithelial cells was analysed by ELISA.

Results: The results of our study showed that unstimulated cells of UC patients had a decreased viability, increased ROS production, but similar TNF-a level when compared to the controls. Stimulation with LPS increased hydrogen peroxide and TNF-a level in the UC group. Treatment of colonic epithelial cells with NADPH oxidase inhibitor increased cell viability decreased the levels of ROS and TNF-a in the LPS-treated cells isolated from UC patients.

Conclusions: Our study showed that bacterial endotoxins induced NADPH oxidase activation in the colonic epithelial cells. Moreover, we revealed that treatment with NADPH oxidase inhibitors had a protective effect against pro-inflammatory action of LPS in human colonic epithelium cells during inflammation.
\end{abstract}

Keywords: Cell-biology, Cytokines, Ulcerative colitis, NADPH oxidase

\section{Background}

Ulcerative colitis (UC) is a chronic inflammatory bowel disease (IBD) that affects intestinal mucosa. The pathogenic mechanisms of UC are complex and involve interaction between genetic, host immune system and environmental factors. One of the major factors in the onset of $\mathrm{UC}$ is inappropriate mucosal immune response towards the intestinal microbiota leading to mucosal tissue damage and chronic inflammation [1-3].

\footnotetext{
*Correspondence: I.kupcinskas@gmail.com

${ }^{\dagger}$ Equal contributors

IInstitute for Digestive Research, Academy of Medicine, Lithuanian University of Health Sciences, A. Mickeviciaus str. 9, LT-44307 Kaunas, Lithuania

${ }^{2}$ Department of Gastroenterology, Academy of Medicine, Lithuanian University of Health Sciences, A. Mickeviciaus str. 9, LT-44307 Kaunas, Lithuania

Full list of author information is available at the end of the article
}

Increased production of reactive oxygen species (ROS) and oxidant-induced protein or lipid alterations have been implicated in tissue damage observed in chronic inflammatory disorders, such as IBD [4]. The key producers of the superoxide anions in the colon are nonphagocytic and phagocytic cells. The epithelial NADPH oxidase homologs (Nox1, Nox3, Nox4, Nox5, DUOX1, and DUOX2) generate a higher level of superoxide in the colon compared to phagocyte NADPH oxidase [5]. Previous studies have shown that epithelial NADPH oxidase mediating formation of ROS might be involved in host defence system and inflammatory responses at mucosal surfaces [6-8]. ROS production in the intestinal mucosal biopsies is increased during inflammation [9]. Moreover, genetic mutations in genes encoding components of the NADPH complex have been associated with IBD susceptibility. The variations have been found in

\section{Biomed Central}


genes responsible for localization of the NADPH oxidase complex (including p47phox and p67phox and RAC2) to the membrane $[10,11]$.

Despite the profound consequences of either absent or excessive ROS generation in the intestinal tract, little is known about the molecular pathways controlling ROS production via NOX enzymes in the primary intestinal epithelial cells derived from UC patients. Therefore, in this study we aimed to evaluate the role of NADPH oxidase in primary intestinal epithelial cells during the active phase of UC.

\section{Methods}

\section{Patients}

The colonoscopic biopsies were obtained from 19 patients with $\mathrm{UC}$ (men $\mathrm{n}=9$ (medium age $\pm \mathrm{SD}=45.8 \pm 20.1$ ), women $\mathrm{n}=10$ (medium age $\pm \mathrm{SD}=42 \pm 18$ )) and 14 control subjects (men $\mathrm{n}=7$ (medium age $\pm \mathrm{SD}=44 \pm 19.5$ ), women $n=7$ (medium age (years \pm SD) $=47 \pm 15.3$ )). UC patients and control subjects were recruited in the Department of Gastroenterology, Hospital of Lithuanian University of Health Sciences. The diagnosis of UC was based on standard clinical, endoscopic, radiological, and histological criteria [12-14]. Patients with mild to moderate disease activity were included in the study (Mayo UC Endoscopic Score 1 to 2). Histologically, these patients had active chronic UC as well. The individuals did not use steroid or immunosuppressive therapy at least 3 months before the biopsies specimens have been obtained. Only five patients had used 5-aminosalicylate (5-ASA) preparations as maintenance therapy $(\leq 1.5 \mathrm{~g} / \mathrm{d})$. None of the patients had received iron supplementation.

The control group consisted of patients with irritable bowel disease or functional constipation. Individuals were included if they had a normal colonoscopy and uninflamed mucosa on histopathological examination. All patients had a routine colonoscopy performed as a part of their planned examination programme. In healthy subjects, eight to ten biopsies (5-10 mg wet weight each) were taken from transverse or descending colon. The same numbers of biopsies from patients with UC were collected from endoscopically inflamed colonic mucosa. Biopsies were immediately placed in a chilled Dulbecco's modified Eagle medium containing $10 \mathrm{mM}$ HEPES buffer and antibiotics (50 IU/ml penicillin, $50 \mathrm{mg} / \mathrm{ml}$ streptomycin and $0.5 \mathrm{mg} / \mathrm{ml}$ of gentamicin). Written informed consent was obtained from all study participants. The study has been approved by the Kaunas Regional Biomedical Research Ethics Committee (Protocol No. BE - 2-49).

\section{Isolation and cultivation of primary human colonic epithelial cells}

All chemicals were obtained from Sigma-Aldrich (Steinheim, Germany) unless otherwise stated. The primary human colonic epithelial cells were isolated using chelation method according to Seidelin et al. [15]. The incubation time in the chelation buffer lasted for 40-45 min at room temperature that allowed the isolation of single epithelial cells. The isolated epithelial cells were suspended in DMEM with 15\% fetal calf serum (FCS), 10 mM HEPES buffer and antibiotics. Approximately $10^{7}$ cells per well were cultured with mediators $(20 \mu \mathrm{g} / \mathrm{ml}$ of lipopolysaccharide (LPS), $1 \mathrm{mM}$ of apocynin, $20 \mu \mathrm{g} / \mathrm{ml} \mathrm{LPS}+1 \mathrm{mM}$ apocynin, 200 units $/ \mathrm{ml}$ of catalase) in 24-well plates coated with bovine dermal collagen for 24 hours at $37^{\circ} \mathrm{C}$ in an atmosphere of $5 \% \mathrm{CO}_{2}$ and at $90 \%$ relative humidity. After 24 hours, supernatants were collected and stored at $-20^{\circ} \mathrm{C}$.

\section{Measurement of hydrogen peroxide production}

$\mathrm{NADPH}$ oxidase generates superoxide, which is rapidly converted to hydrogen peroxide [16]. Hydrogen peroxide production in cells was measured fluorimetrically using $1 \mu \mathrm{M}$ Amplex Red and 10 units/ml Horseradish peroxidase. Colonic epithelial cells (approximately $10^{5}$ cells $/ \mathrm{ml}$ ) were re-suspended in the phosphate-buffered saline (PBS) and incubated with either 5 units $/ \mathrm{ml}$ of catalase (endogenous control), or $10 \mu \mathrm{g} / \mathrm{ml}$ of LPS, or $10 \mu \mathrm{M}$ of diphenylene iodonium (DPI), or $10 \mu \mathrm{g} / \mathrm{ml} \mathrm{LPS}+10 \mu \mathrm{M}$ DPI for $30 \mathrm{~min}$ at $37^{\circ} \mathrm{C}$. Then the Amplex Red and peroxidase were added and the rate of hydrogen peroxide production was quantitated at $544 \mathrm{~nm}$ excitation and $590 \mathrm{~nm}$ emission by a microplate fluorometer (Fluoroskan Ascent, Thermo Fisher Scientific, Waltham, MA).

Apocynin (used as NADPH oxidase inhibitor during cell cultivation) interferes with detection of ROS in assay systems selective for hydrogen peroxide or hydroxyl radicals. This inhibitor acts as a radical scavenger and inhibits Amplex Red oxidation. Thus ROS are not measured accurately and cannot reflect the effect of apocynin on the NADPH oxidase activity [17]. Therefore, for the assessment of NADPH oxidase activity we applied another large-spectrum inhibitor DPI.

\section{Assessment of cell viability}

The viability of human colonic epithelial cells in the cultures was assessed by propidium iodide (PI, $7 \mu \mathrm{M})$ and Hoechst $33342(4 \mu \mathrm{g} / \mathrm{ml})$ staining using a fluorescence microscope (OLYMPUS IX71S1F-3, Tokyo, Japan). PInegative cells with weak Hoechst-staining were considered to be viable, whereas cells showing nuclear shrinkage or fragmentation and intensive Hoechst staining but still lacking PI staining were classified as chromatin condensed/fragmented (apoptotic). PI-positive cells were classified as necrotic. Human colonic epithelial cells were counted in at least 5 microscopic fields per well (three wells per treatment). Data are expressed as percentage of 
viable, necrotic or apoptotic cells of the total number of cells per field.

\section{Assessment of TNF - $a$ concentration}

Concentration of TNF- $\alpha$ was assessed in the supernatants of primary colonic epithelial cells cultures using commercially available two-site ELISA kit (Invitrogen, Carlsbad, CA). The lowest limit of sensitivity of test systems for TNF- $\alpha$ was $3 \mathrm{pg} / \mathrm{ml}$. The optical densities at $450 \mathrm{~nm}$ and at a correction wavelength of $490 \mathrm{~nm}$ were measured on ELISA micro plate reader (MRX micro plate reader, Dynex Technologies, Denkendorf, Germany).

\section{Statistical analysis}

Statistical analyses were done using the SPSS statistical package (version 16.0; Chicago, IL). Data in text and figures are presented as means \pm standard error (SE). The results were analysed by one-way ANOVA. The least significant difference (LSD) test was used as a post hoc test. $P$-value of $<0.05$ was accepted as statistically significant.

\section{Results}

Assessment of viability of human colonic epithelial cells Firstly, we investigated whether there was any difference in survival of colonic epithelial cells isolated from UC patients and control individuals in cell culture. As shown in Figure 1, after $24 \mathrm{~h}$ in culture the vast majority of the control cells were viable and accounted for $72 \%$, necrosis was observed in $18 \%$ and apoptosis in $10 \%$ of cells. The viability of cells isolated from UC patients and maintained in cell culture for $24 \mathrm{~h}$ was significantly lower than in control group (Figure 1A and B). Treatment of cells with NADPH oxidase inhibitor apocynin or with catalase (which selectively removes $\mathrm{H}_{2} \mathrm{O}_{2}$ ) increased the viability of the UC group cells reaching the survival level of untreated cells. In contrast, apocynin as well as catalase had no effect on cell survival in the control group.

Stimulation of colonic epithelial cells with LPS significantly reduced the number of live cells from $72 \%$ to $57 \%$ and increased necrotic cell death from 18\% to $37 \%$ in the control group; whereas the viability of cells in UC group remained unchanged upon LPS treatment (Figure 1B). The cultivation of cells with LPS and apocynin increased the viability of the cells in the control and UC groups (to $76 \%$ and $78 \%$, respectively) by decreasing the number of necrotic cells (Figure 1A and B). The percentage of apoptotic cells was $5-8 \%$ in all study groups.

\section{Assessment of hydrogen peroxide production in cells}

Further, we analysed the ROS generation in primary colonic epithelial cells. As shown in Figure 2, the level of extracellular hydrogen peroxide production was approximately two times higher in epithelial cells of UC patients compared to the control group. Similar results were
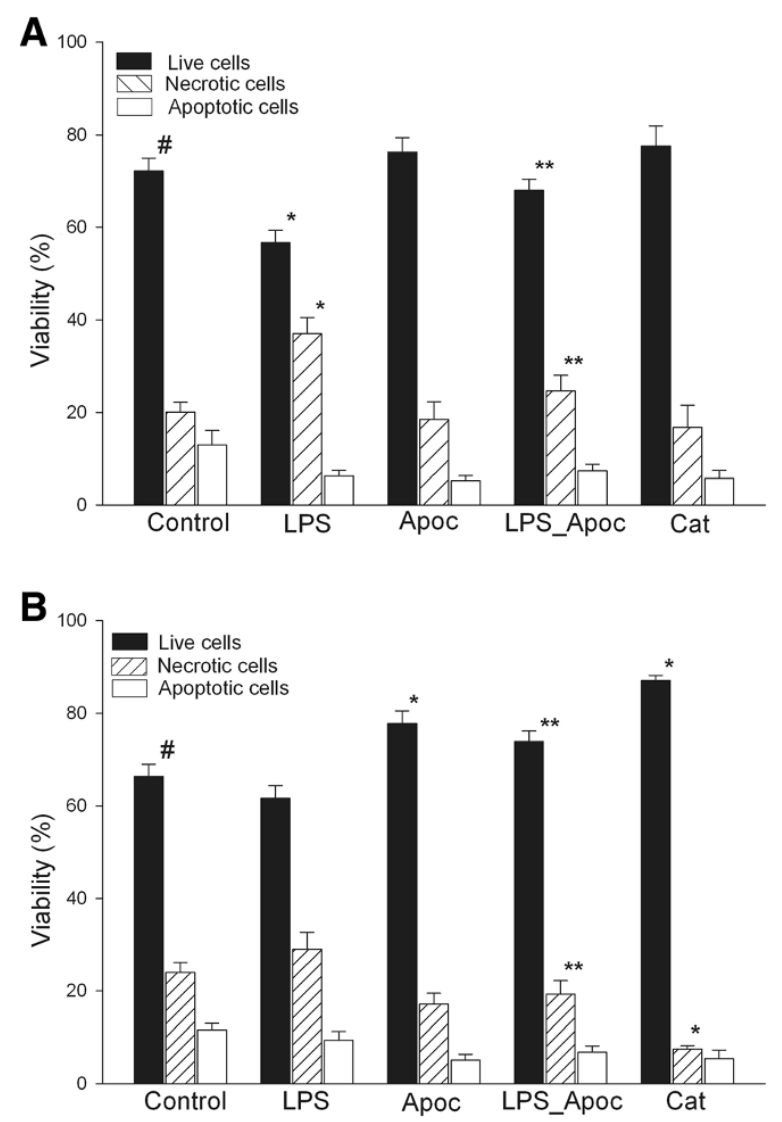

Figure 1 Assessment of viability of human colonic epithelial cells. Where indicated, cells were incubated with $20 \mu \mathrm{g} / \mathrm{ml}$ LPS, $1 \mathrm{mM}$ apocynin (apoc), $20 \mathrm{\mu g} / \mathrm{ml} \mathrm{LPS}+1 \mathrm{mM}$ apocynin, $200 \mathrm{units} / \mathrm{ml}$ catalase (Cat), and control without stimulation for 24 h. A - control group, B - UC group. "Statistically significant difference between control and another subgroups in the control or UC groups. ** Statistically significant difference between LPS and LPS + Apocynin subgroups in the control or UC groups. "Statistically significant difference between control and UC groups. Statistically significant, as $p<0.05$.

obtained when hydrogen peroxide production was measured directly in the colonic biopsies (Figure 2B). The treatment of colonic epithelial cells with catalase significantly decreased the level of extracellular hydrogen peroxide production in both experimental groups.

DPI slightly decreased the level of ROS production in both UC and control groups, however, the differences were not statistically significant. The treatment of cells with LPS significantly increased the production of hydrogen peroxide in cells of both study groups (Figure 2A). The addition of DPI to LPS-treated colonic epithelial cells significantly decreased (by 1.7 fold) the level of ROS production in the UC group. In control group, DPI also diminished hydrogen peroxide production in LPStreated cells, though the effect of DPI per se was not statistically significant due to higher variability of results (Figure 2A). 


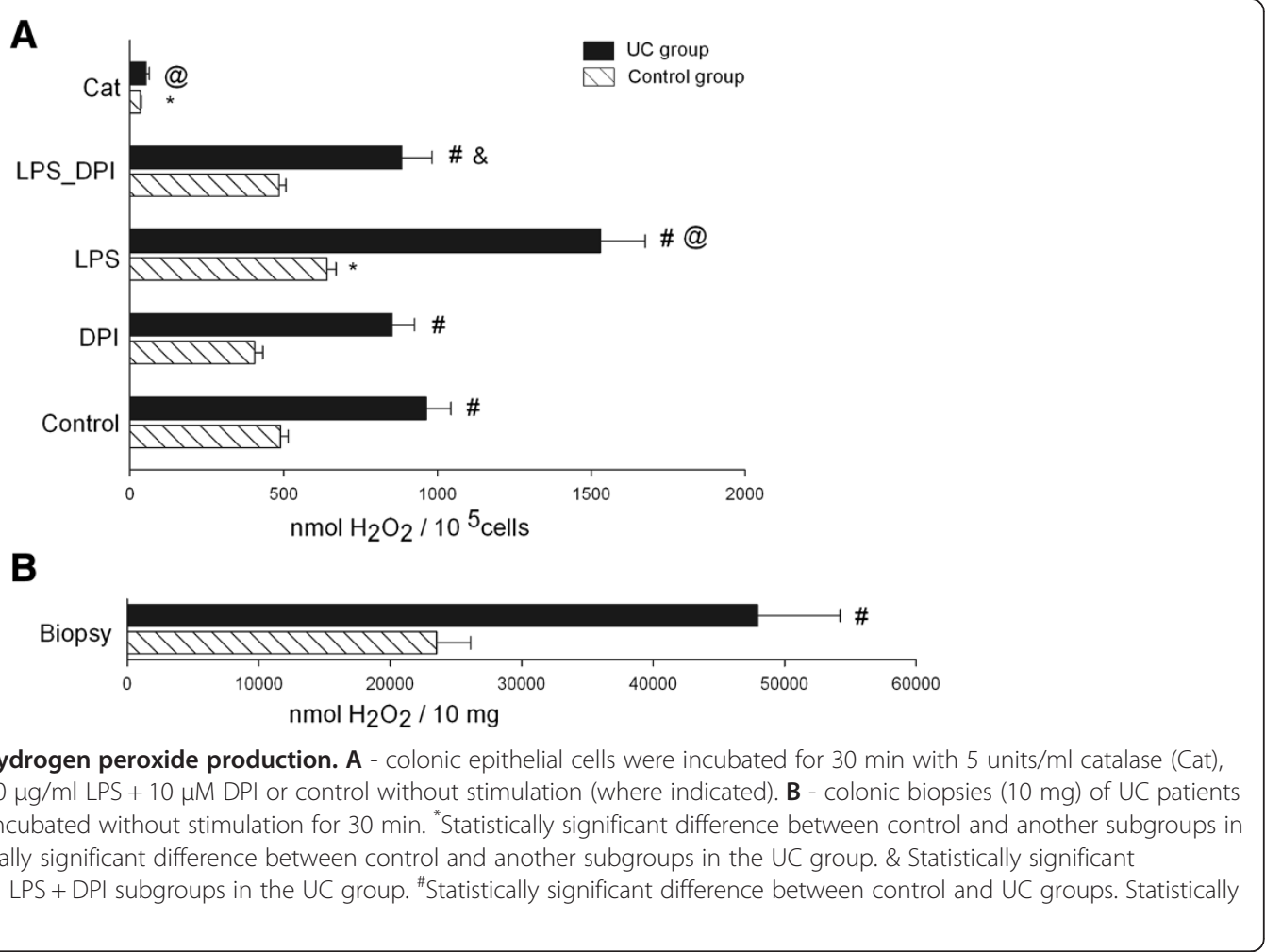

\section{Assessment of TNF- $a$ concentration in the colonic epithelial cells}

In addition, we analysed the influence of NADPH oxidase on the production of pro-inflammatory cytokine TNF- $\alpha$. As shown in Figure 3, the highest concentrations of TNF- $\alpha$ were determined in cells of UC patients after stimulation with LPS. The level of cytokine production was approximately three-fold higher in LPS treated UC cells when compared to UC cells without stimulation and control group cells treated with LPS. In the UC group, treatment of cells with LPS and NADPH oxidase inhibitor apocynin decreased the levels of TNF- $\alpha$ production approximately 2.5 -fold as compared with the LPS treated colonic epithelial cells. The differences of TNF- $\alpha$ concentration between untreated and treated cells in the control group were insignificant.

\section{Discussion}

Functional studies have indicated that increased activity of NADPH oxidase contributes to the development of colon inflammation [5,18]. Inhibition of this enzyme represents an attractive therapeutic target for the treatment of many diseases. Apocynin has been used as an inhibitor of the complex NADPH oxidase in many experimental models of inflammation involving phagocytic and non-phagocytic cells [19-21]. In this study, we examined the influence of superoxide generating NADPH oxidase in primary intestinal epithelial cells during the active phase of UC.

In the current study we showed that unstimulated cells of UC patients had a decreased viability, increased ROS production, and similar TNF- $\alpha$ level when compared to

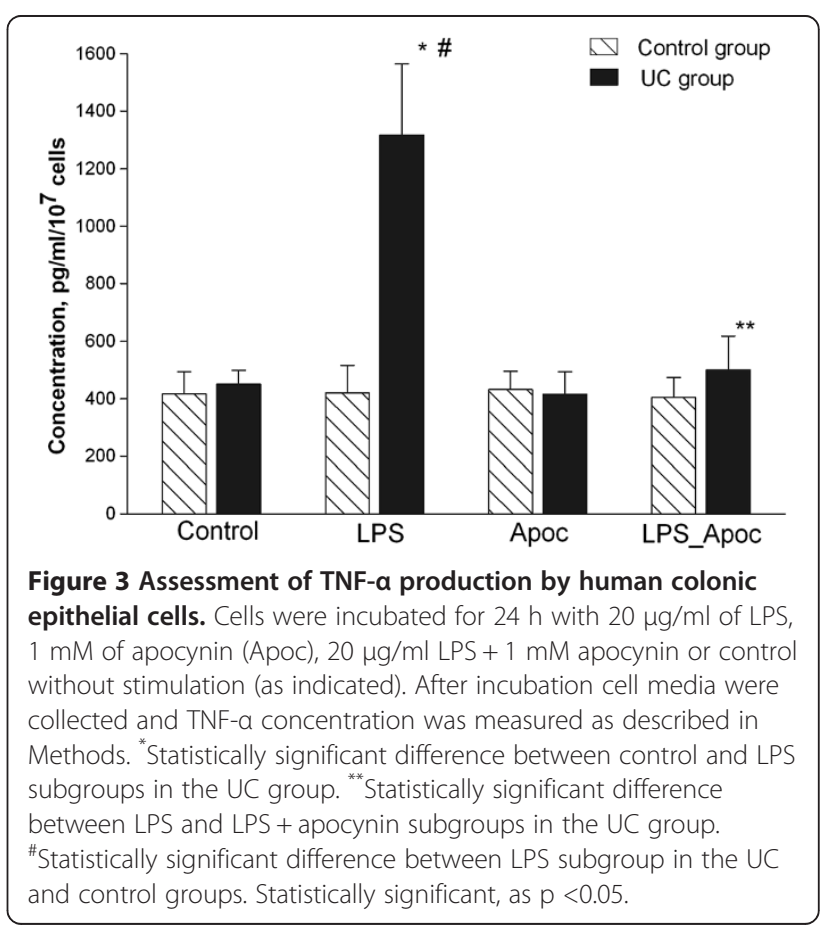


the control group. These findings are characteristic of $\mathrm{UC}$ as increased cell death and excessive ROS production are typical processes on-going during inflammation. Previous studies have shown that the level of TNF- $\alpha$ may correlate with the grade of inflammation in UC $[22,23]$. Similar levels of TNF- $\alpha$ observed in UC and control groups could be linked with absence of severe disease activity cases within our cohort of UC patients.

The results of our study showed that sensitisation of colonic epithelial cells with bacterial products were required for activation of NADPH oxidase. Cell viability in normal epithelial cells was dramatically decreased in the presence of LPS and assessment of extracellular hydrogen peroxide production showed increase in ROS production. This observation suggests that innate immune system may activate protective cascades against microbial invaders; whereas minor changes in TNF- $\alpha$ level may indicate suspended immune response towards microbial products. It is well known that ROS production is rapidly elevated during infection, serving to facilitate pathogen clearance as well as contributing to signalling cascades related to inflammation, cell proliferation, and immune responses [24]. In the UC group the response to microbial stimulation resulted in an increased production of oxidants and pro-inflammatory cytokine [24,25]. LPS-induced inflammatory responses are more intense and acute in UC patients because mechanisms responsible for bacterial recognition are unbalanced [25]. However, we cannot exclude the possibility that the presence of phagocytic cells might have affected ROS production and TNF$\alpha$ concentration in the cell cultures from UC patients.

Animal models and in vitro cell culture studies have shown that apocynin possesses anti-inflammatory activity [19] and protects non-phagocytic cells from damage induced by bacterial products and can reduce damage in the colon tissues [26-28]. However, the impact of NADPH oxidase inhibitory components has not been previously shown in primary colon epithelial cell cultures. The impact of apocynin in our control group was minor; whereas in the UC group the inhibitor significantly increased cell viability and reduced TNF- $\alpha$ in the LPS-treated colonic epithelial cells. These findings indicate that NADPH oxidase inhibition has an anti-inflammatory effect in human colonic epithelium cells during inflammation. Similar findings have been observed in lung endothelial cells during inflammation. The suppression of NADPH oxidase activity by apocynin in the lung endothelial cells resulted in a significant reduction of all parameters of inflammation measured, including TNF- $\alpha$ level $[29,30]$.

The results of this study confirmed that NADPH oxidase is directly involved in LPS-induced ROS generation in the primary colonic epithelial cells and revealed the inflammation reducing effect of NADPH oxidase inhibitors. Based on the findings observed in the studies performed in the cancer cell cultures $[27,31]$, we suggest that a molecular mechanism for activation of NADPH oxidase in colonic epithelial cells may be associated with a toll-like receptor (TLR) pathway, where LPS strains potently stimulate ROS production by colon NADPH oxidase through a TLR4 [31-33]. Further studies should be designed to determine the mechanism of LPS/TLR4/TNF- $\alpha /$ colon NADPH oxidase signalling in colonic epithelial cells and its contribution to UC etiopathogenesis.

\section{Conclusion}

In conclusion, we showed that bacterial endotoxins were required for NADPH oxidase activation in the colonic epithelial cells. Moreover, we revealed that treatment with NADPH oxidase inhibitors had a protective effect against pro-inflammatory action of LPS in human colonic epithelium cells during inflammation.

\section{Competing interests}

The authors declare that they have no competing interests.

\section{Authors' contributions}

RR, JS - Performed experiments, analysed data, interpreted results of experiments, prepared figures, drafted manuscript. PC - Performed experiments, analysed data. GK, LVJ, AT - interpreted results of experiments, edited and revised manuscript. VB, LK - Conception and design of research, interpreted results of experiments, approved final version of manuscript. All authors read and approved the final manuscript.

\section{Acknowledgments}

This study was supported by the Lithuanian state Science and studies foundation (Title of project: "Molecular mechanism of bacteria recognition in colonic epithelial cells and its association with inflammatory bowel disease etiopathogenesis", Project no. T-39/08).

\section{Author details}

${ }^{1}$ Institute for Digestive Research, Academy of Medicine, Lithuanian University of Health Sciences, A. Mickeviciaus str. 9, LT-44307 Kaunas, Lithuania. ${ }^{2}$ Department of Gastroenterology, Academy of Medicine, Lithuanian University of Health Sciences, A. Mickeviciaus str. 9, LT-44307 Kaunas, Lithuania. ${ }^{3}$ Department of Surgery, Academy of Medicine, Lithuanian University of Health Science, A. Mickeviciaus str. 9, LT-44307 Kaunas, Lithuania. Institute for Neurosciences, Academy of Medicine, Lithuanian University of Health Sciences, A. Mickeviciaus str. 9, LT-44307 Kaunas, Lithuania.

Received: 2 January 2013 Accepted: 11 November 2013

Published: 14 November 2013

\section{References}

1. Iwamoto M, Koji T, Makiyama K: Apoptosis of crypt epithelial cells in ulcerative colitis. J Pathol 1996, 180(2):152-159.

2. Siggers $\mathrm{RH}$, Hackam DJ: The role of innate immune-stimulated epithelial apoptosis during gastrointestinal inflammatory diseases. Cell Mol Life Sci 2011, 68(22):3623-3634.

3. Cooney $R$, Jewell $D$ : The genetic basis of inflammatory bowel disease. Digest Dis 2009, 27:428-442.

4. McKenzie SJ, Baker MS, Buffinton GD, Doe WF: Evidence of oxidantinduced injury to epithelial cells during inflammatory bowel disease. J Clin Invest 1996, 98(1):136-141.

5. Bedard K, Krause KH: The NOX family of ROS-generating NADPH oxidases: physiology and pathophysiology. Physiol Rev 2007, 87(1):245-313.

6. Kawahara T, Kuwano Y, Teshima-Kondo S, Takeya R, Sumimoto H, Kishi K, Tsunawaki S, Hirayama T, Rokutan K: Role of nicotinamide adenine dinucleotide phosphate oxidase 1 in oxidative burst response to Toll-like 
receptor 5 signaling in large intestinal epithelial cells. J Immunol 2004, 172(5):3051-3058.

7. Park HS, Jung HY, Park EY, Kim J, Lee WJ, Bae YS: Cutting edge: direct interaction of TLR4 with NAD(P)H oxidase 4 isozyme is essential for lipopolysaccharide-induced production of reactive oxygen species and activation of NF-kappa B. J Immunol 2004, 173(6):3589-3593.

8. El-Benna J, Dang PM, Gougerot-Pocidalo MA: Role of the NADPH oxidase systems Nox and Duox in host defense and inflammation. Expert Rev Clin Immunol 2007, 3(2):111-115.

9. Davies GR, Simmonds NJ, Stevens TR, Grandison A, Blake DR, Rampton DS: Mucosal reactive oxygen metabolite production in duodenal ulcer disease. Gut 1992, 33(11):1467-1472.

10. Rioux JD, Xavier RJ, Taylor KD, Silverberg MS, Goyette P, Huett A, Green T, Kuballa P, Barmada MM, Datta LW, Shugart YY, Griffiths AM, Targan SR, Ippoliti AF, Bernard EJ, Mei L, Nicolae DL, Regueiro M, Schumm LP, Steinhart AH, Rotter Jl, Duerr RH, Cho JH, Daly MJ, Brant SR: Genome-wide association study identifies new susceptibility loci for Crohn disease and implicates autophagy in disease pathogenesis. Nat Genet 2007, 39(5):596-604.

11. Muise AM, Xu W, Guo CH, Walters TD, Wolters VM, Fattouh R, Lam GY, Hu P, Murchie R, Sherlock M, Gana JC NEOPICS, Russell RK, Glogauer M, Duerr RH, Cho JH, Lees CW, Satsangi J, Wilson DC, Paterson AD, Griffiths AM, Silverberg MS, Brumell JH: NADPH oxidase complex and IBD candidate gene studies: identification of a rare variant in NCF2 that results in reduced binding to RAC2. Gut 2012, 61(7):1028-1035.

12. Podolsky DK: Inflammatory bowel disease. N Engl J Med 1991, 325(13):928-937.

13. Schroeder KW, Tremaine WJ, Ilstrup DM: Coated oral 5-aminosalicylic acid therapy for mildly to moderately active ulcerative colitis. A randomized study. N Engl J Med 1987, 317:1625-1629.

14. Riley SA, Mani V, Goodman MJ, Dutt S, Herd ME: Microscopic activity in ulcerative colitis: what does it mean? Gut 1991, 32(2):174-178.

15. Seidelin JB, Horn T, Nielsen $\mathrm{OH}$ : Simple and efficient method for isolation and cultivation of endoscopically obtained human colonocytes. Physiol Gastrointest Liver Physiol 2003, 285(6):G1122-G1128.

16. Babior BM: NADPH oxidase. Curr Opin Immunol 2004, 16(1):42-47.

17. Heumüller S, Wind S, Barbosa-Sicard E, Schmidt HH, Busse R, Schröder K, Brandes RP: Apocynin is not an inhibitor of vascular NADPH oxidases but an antioxidant. Hypertension 2008, 51(2):211-217.

18. Szanto I, Rubbia-Brandt L, Kiss P, Steger K, Banfi B, Kovari E, Herrmann F, Hadengue A, Krause KH: Expression of NOX1, a superoxide-generating NADPH oxidase, in colon cancer and inflammatory bowel disease. J Pathol 2005, 207(2):164-176.

19. Stefanska J, Pawliczak R: Apocynin: molecular aptitudes. Mediators Inflamm 2008, 106:507. doi:10.1155/2008/106507.

20. Choi EM, Lee YS: Protective effect of apocynin on antimycin A-induced cell damage in osteoblastic MC3T3-E1 cells. J App/ Toxicol 2012, 32(9):714-721.

21. Palmen MJH, Beukelman CJ, Mooij RGM, Pena AS, Van-Rees EP: Anti-inflammatory effect of apocynin, a plant-derived NADPH oxidase antagonist, in acute experimental colitis. Netherl J Med 1995, 47(2):A41-A41.

22. Masuda H, Iwai S, Tanaka T, Hayakawa S: Expression of IL-8, TNF-alpha and IFN-gamma m-RNA in ulcerative colitis, particularly in patients with inactive phase. J Clin Lab Immunol 1995, 46:111-123.

23. Olsen T, Goll R, Cui G, Husebekk A, Vonen B, Birketvedt GS, Florholmen J: Tissue levels of tumor necrosis factor-alpha correlates with grade of inflammation in untreated ulcerative colitis. Scand J Gastroenterol 2007 42(11):1312-1320.

24. Sareila O, Kelkka T, Pizzolla A, Hultqvist M, Holmdahl R: NOX2 complexderived ROS as immune regulators. Antioxid Redox Signal 2011, 15(8):2197-2208

25. Maloy KJ, Powrie F: Intestinal homeostasis and its breakdown in inflammatory bowel disease. Nature 2011, 474(7351):298-306.

26. Marin M, Giner RM, Rios JL, Recio Mdel C: Protective effect of apocynin in a mouse model of chemically-induced colitis. Planta Med 2013, 79(15):1392-1400.

27. Hershberg RM: The epithelial cell cytoskeleton and intracellular trafficking. V. Polarized compartmentalization of antigen processing and Toll-like receptor signaling in intestinal epithelial cells. Am J Physiol Gastrointest Liver Physiol 2002, 283(4):G833-G839.

28. Van den Worm E, Beukelman CJ, Van den Berg AJ, Kroes BH, Labadie RP, Van Dijk H: Effects of methoxylation of apocynin and analogs on the inhibition of reactive oxygen species production by stimulated human neutrophils. Eur J Pharmacol 2001, 433(2-3):225-230.

29. Impellizzeri D, Esposito E, Mazzon E, Paterniti I, Di Paola R, Bramanti P, Cuzzocrea S: Effect of apocynin, a NADPH oxidase inhibitor, on acute lung inflammation. Biochem Pharmacol 2011, 81(5):636-648.

30. Wu F, Tyml K, Wilson JX: iNOS expression requires NADPH oxidasedependent redox signaling in microvascular endothelial cells. J Cell Physiol 2008, 217:207-214

31. Rokutan K, Kawahara T, Kuwano Y, Tominaga K, Nishida K, Teshima-Kondo S: Nox enzymes and oxidative stress in the immunopathology of the gastrointestinal tract. Semin Immunopathol 2008, 3:315-327.

32. Rada B, Leto TL: Oxidative innate immune defenses by Nox/Duox family NADPH Oxidases. Contrib Microbiol 2008, 15:164-187.

33. Geiszt M, Leto TL: The Nox Family of NAD (P) H Oxidases: host defense and beyond. J Biol Chem 2004, 279(50):51715-51718.

doi:10.1186/1471-230X-13-159

Cite this article as: Ramonaite et al.: Influence of NADPH oxidase on inflammatory response in primary intestinal epithelial cells in patients with ulcerative colitis. BMC Gastroenterology 2013 13:159.

\section{Submit your next manuscript to BioMed Central and take full advantage of:}

- Convenient online submission

- Thorough peer review

- No space constraints or color figure charges

- Immediate publication on acceptance

- Inclusion in PubMed, CAS, Scopus and Google Scholar

- Research which is freely available for redistribution 